\title{
ANALYTICAL INVESTIGATION AND IMPROVEMENT OF PERFORMANCE OF A PROTON EXCHANGE MEMBRANE (PEM) FUEL CELL IN MOBILE APPLICATIONS
}

\author{
I. KHAZAEE \\ Faculty of Mechanical and Energy Engineering \\ Shahid Beheshti University, A.C. \\ Tehran, IRAN \\ E-mail: Imankhazaee@yahoo.com
}

\begin{abstract}
In this study, the performance of a proton exchange membrane fuel cell in mobile applications is investigated analytically. At present the main use and advantages of fuel cells impact particularly strongly on mobile applications such as vehicles, mobile computers and mobile telephones. Some external parameters such as the cell temperature $\left(T_{\text {cell }}\right)$, operating pressure of gases $(P)$ and air stoichiometry $\left(\lambda_{\text {air }}\right)$ affect the performance and voltage losses in the PEM fuel cell. Because of the existence of many theoretical, empirical and semi-empirical models of the PEM fuel cell, it is necessary to compare the accuracy of these models. But theoretical models that are obtained from thermodynamic and electrochemical approach, are very exact but complex, so it would be easier to use the empirical and smi-empirical models in order to forecast the fuel cell system performance in many applications such as mobile applications. The main purpose of this study is to obtain the semi-empirical relation of a PEM fuel cell with the least voltage losses. Also, the results are compared with the existing experimental results in the literature and a good agreement is seen.
\end{abstract}

Key words: PEM fuel cell, performance, semi-empirical, mobile application.

\section{Introduction}

A fuel cell is an electro-chemical energy device that converts the chemical energy of fuel directly into electricity and heat, with water as a by-product of the reaction. Based on the types of electrolytes used, they are categorized into polymer electrolyte membrane fuel cells (PEMFCs), solid oxide fuel cells (SOFCs), phosphoric acid fuel cells (PAFCs), molten carbonate fuel cells (MCFCs), and direct methanol fuel cells (DMFCs). The polymer exchange membrane fuel cell (PEMFC) is considered to be the most promising candidate for electric vehicles by virtue of its high power density, zero pollution, low operating temperature, quick start-up capability and long lifetime. PEMFC can also be used in distributed power systems, submarines, and aerospace applications (Larminie and Dicks, 2003). The polymer electrolytes work at low temperature, which brings this further advantage that a PEM fuel cell can start quickly.

Figure 1 shows a single cell of the proton exchange membrane fuel cell with parallel straight channels on both the anode and the cathode carbon plates. The single-cell PEMFC consists of a carbon plate, a gas diffusion layer (GDL), a catalyst layer, for each of the anode and the cathode sides, as well as a PEM membrane at the center. As also indicated in Fig.1, oxidation and reduction fuel-cell half reactions take place in the anode and the cathode active layers, respectively. 


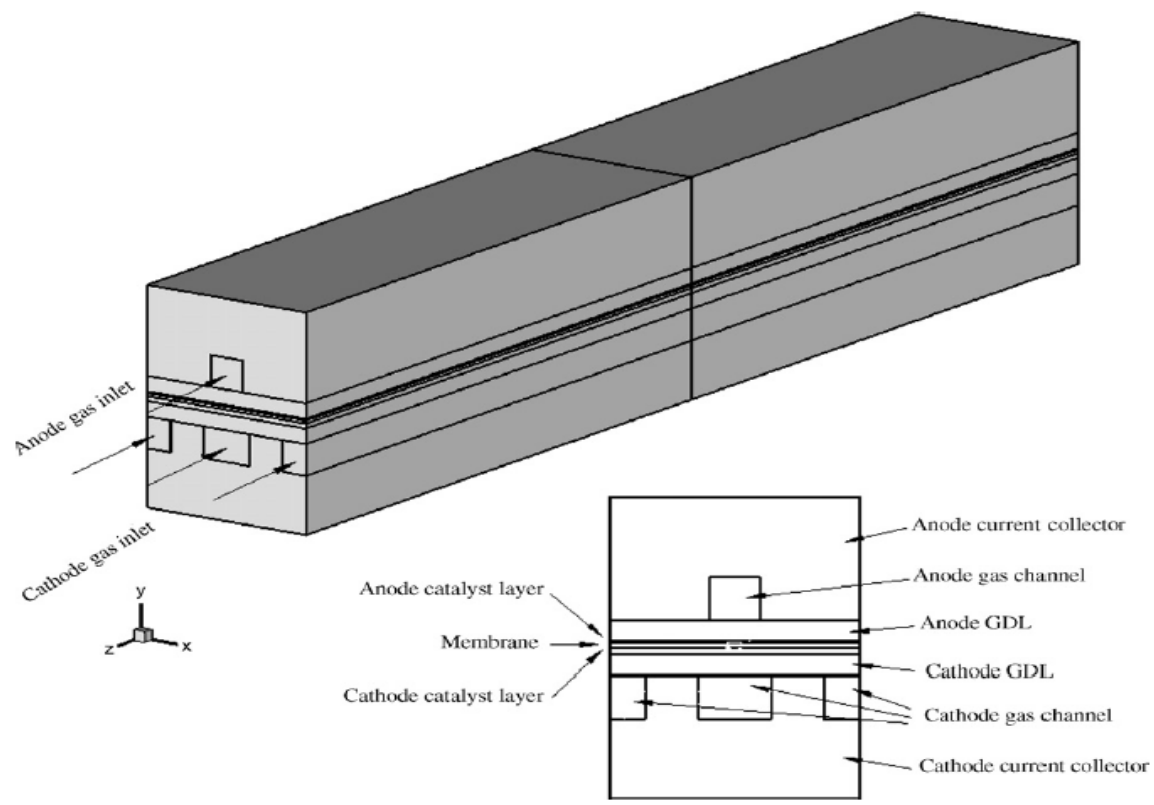

Fig.1. Schematic illustration of a PEM fuel cell.

Based on available literature, the present study analytically investigated the effect of some parameters such as cell temperature, pressure and air stoichiometry on the performance and voltage losses of a PEM fuel cell and compared the existing theoretical and semi-empirical models of a PEM fuel cell. The objective of the current work is to show the differences between models of performance of a proton exchange membrane fuel cell at different operating conditions and the results were compared with the available data.

Xue and Dong (1998) used a semi-empirical model of the Ballard Mark IV fuel cell and models for the auxiliary systems to create a model of the fuel cell system. Using this model and numerical optimization, the optimal active stack area and air stoichimetric ratio were obtained to maximize the net power output, and at the same time minimize the production costs.

Crockett et al. (1995) investigated an electrolyser-based electricity management as a rational solution, allowing supply and demand to be out of phase in time but matched in magnitude. They also recognized PEM fuel cells to have the largest potential due to a comparatively small electrolyte volume, which required only small amounts of hydrogen and oxygen in solution with it.

Amphlett et al. $(1995 \mathrm{a} ; \mathrm{b})$ investigated a theoretical model which was employed to provide the structure of the equations, and then, the parameters of these equations were found by using the regression techniques to fit the experimental results. Also, they studied a semi-empirical model with a theoretical background that takes into account the main variables of the fuel cell operation such as the operating temperature, the partial pressures at the electrodes and the fuel cell current.

\section{Fuel cell models}

A proton exchange membrane fuel cell uses the following electrochemical reaction which produces heat and electrical current.

$$
\mathrm{H}_{2}+\frac{1}{2} \mathrm{O}_{2} \rightarrow \mathrm{H}_{2} \mathrm{O} \text {. }
$$

This phenomenon in the fuel cell is the change of Gibbs free energy of formation, $\Delta G_{f}$ that gives us the energy released. If the system is reversible, the Gibbs free energy released will be equal to the electrical 
work done moving the charge on one mole of electrons. Electrical work done is $-2 F E$ Joules, so the reversible open circuit voltage of the hydrogen fuel cell is

$$
E=-\frac{\Delta G_{f}}{2 F}
$$

The output voltage of a single cell at any operating condition is given by

$$
V=E_{N}+\eta_{a}+\eta_{o}+\eta_{c}
$$

where $E_{N}$ is the Nernst equation, which is an expression for the electromotive force (EMF) for given product and reactant activities. The (EMF) calculated from such equations is known as the Nernst voltage, and is the reversible cell voltage that would exist at a given temperature and pressure. Also, $\eta_{a}$ stands for the activation losses that are the most important irreversibility and cause of voltage drop, and occur mainly at the cathode, $\eta_{o}$ stand for the Ohmic losses that are due to the electrical resistance of the electrodes, and the resistance to the flow of ions in the electrolyte and finally $\eta_{c}$ is the concentration losses, which is the voltage lost when the concentration of reactant at the electrode is diminished.

The Nernst voltage for a hydrogen fuel cell is

$$
E_{N}=E^{\circ}-0.85 \times 10^{-3}\left(T_{\text {cell }}-298.15\right)+4.31 \times 10^{-5} T_{\text {cell }}\left[\ln \left(p_{H_{2}}^{\text {contact }}\right)+0.5 \ln \left(p_{o_{2}}^{\text {contact }}\right)\right]
$$

where $E^{\circ}$ is the open circuit voltage and it is equal to $E^{\circ}=1.229 \mathrm{~V}, T_{\text {cell }}$ is the surface cell temperature $(K)$, $p_{\mathrm{H}_{2}}^{\text {contact }}$ is the hydrogen partial pressure (bar) at the surface of catalyst and anode and $p_{o_{2}}^{\text {contact }}$ is the oxygen partial pressure at the surface of catalyst and cathode (Amphlett, 1995) as

$$
\begin{aligned}
& p_{H_{2}}^{\text {contact }}=\left(1 / 2 p_{H_{2}}^{\text {sat }}\right)\left[\frac{1}{\exp \left(1.653 i / T_{\text {cell }}^{1.334}\right) \cdot x_{H_{2}{ }^{o}}^{\text {sat }}}-1\right], \\
& p_{o_{2}}^{\text {contact }}=P\left[1-x_{H_{2}{ }^{o}}^{\text {sat }}-x_{\text {othergasses }}^{\text {channel }} \exp \left(0.291 i / T_{\text {cell }}^{0.832}\right)\right]
\end{aligned}
$$

where $i$ is the current density, $x_{\mathrm{H}_{2} \mathrm{o}}^{\mathrm{s}}$ is the molar fraction of water in a gas stream at saturation for a given temperature, $\mathrm{p}$ is the cell pressure and $x_{\text {othergasses }}^{\text {channel }}$ is the molar fraction of other gasses apart from oxygen in the air stream.

The molar fractions of water and other gasses are respectively (Amphlett, 1995)

$$
x_{H_{2} o}^{s a t}=\frac{p_{H_{2} o}^{s a t}}{p},
$$




$$
x_{\text {othergasses }}^{\text {channel }}=\frac{0.79\left(1-x_{H_{2}}^{\text {sat }}\right)-\frac{1-x_{H_{2}}^{\text {sat }}}{1+\left(\lambda_{\text {air }}-1 / \lambda_{\text {air }}\right)(0.21 / 0.79)}}{\ln \left[0.79\left(1-x_{H_{2} o}^{\text {sat }}\right) /\left(1-x_{H_{2}}^{\text {sat }}\right) /\left(1+\left(\lambda_{\text {air }}-1 / \lambda_{\text {air }}\right)(0.21 / 0.79)\right)\right]}
$$

where $\lambda_{\text {air }}$ is the stoichiometry of the air stream and the 0.21 term and 0.79 term refer to the dry molar fraction of oxygen and other gasses in air. The saturation pressure of water vapor can be computed from the following empirical equation

$$
\ln \left(p_{H_{2}}^{\text {sat }}\right)=70.43464-\frac{7362.698}{T_{\text {cell }}}+0.006952 T_{\text {cell }}-9 \ln \left(T_{\text {cell }}\right)
$$

The activation voltage loss is present when the rate of the electrochemical reaction at the electrode surface is controlled by sluggish electrode kinetics. Activation losses increase as the current increases. The activation losses can be obtained by Tafel equation.

$$
\eta_{a}=\frac{R_{u} T}{2 \alpha F} \ln \left(\frac{i}{i_{0}}\right)=T(a+b \ln (I))
$$

where $\alpha$ is the charge transfer coefficient and $a, b$ are the constants in Tafel equation. The equation of activation loss is proposed as in Mann et al. (2000)

$$
\eta_{a}=\delta_{1}+\delta_{2} T_{\text {cell }}+\delta_{3} T_{\text {cell }} \ln \left(C_{o_{2}}^{\text {cot act }}\right)+\delta_{4} T_{\text {cell }} \ln (I)
$$

where

$$
C_{o_{2}}^{\text {contact }}=\frac{p_{o_{2}}^{\text {contact }}}{5.08 \times 10^{6} \exp \left(-498 / T_{\text {cell }}\right)}
$$

and coefficients $\delta_{j}$ are obtained from the experimental data (Mann et al., 2000) and they are all constant apart from $\delta_{2}$ which varies with the active area of the fuel cell (A)

$$
\begin{aligned}
& \delta_{1}=-0.948, \\
& \delta_{2}=0.00286+0.0002 \ln (A)+4.3 \times 10^{-5} \ln \left(C_{H_{2}}^{\text {contact }}\right), \\
& \delta_{3}=7.6 \times 10^{-5}, \\
& \delta_{4}=-1.93 \times 10^{-4}
\end{aligned}
$$

where 


$$
C_{H_{2}}^{\text {contact }}=\frac{p_{H_{2}}^{\text {contact }}}{1.09 \times 10^{6} \exp \left(77 / T_{\text {cell }}\right)} .
$$

The Ohmic loss is due to the electrical resistance of the electrodes and the resistance to the flow of ions in the electrolyte. The Ohmic loss is proposed in Mann et al. (2000) as

$$
\eta_{o}=-i\left(R^{e l e c}+R^{p r o t}\right)
$$

where $R^{\text {elec }}$ is assumed to be a constant over the operating temperature of the PEM fuel cell. The electronic resistance is further assumed to be inconsequential in comparison to protonic resistance, and is thus ignored. The term $R^{\text {prot }}$ is known to be a complex function of water content and distribution in the membrane, which in turn is a function of the cell temperature and current.

$$
A R^{\text {prot }} / l_{m}=\frac{181.6\left[1+0.03 i+0.062\left(T_{\text {cell }} / 303\right)^{2} i^{2.5}\right]}{(14-3 i) \exp \left(3.25\left(T_{\text {cell }}-303 / T_{\text {cell }}\right)\right)}
$$

where $A$ is the active area and $l_{m}$ is the thickness of the membrane $(\mathrm{cm})$.

The total resistance is proposed in Lazarou et al. (2009)

$$
R^{\text {elec }}+R^{\text {prot }}=0.9859+0.001872 I-0.0023712 T_{\text {cell }} .
$$

In Frangopoulos and Nakos (2006) the Ohmic loss is proposed as

$$
\eta_{o}=-3.3 \times 10^{-3} I+7.55 \times 10^{-6} I T_{\text {cell }}-1.1 \times 10^{-6} I^{2} .
$$

The concentration loss is the loss of voltage, which is the voltage lost when the concentration of the reactant at the electrode is diminished. If the anode of a fuel cell is supplied with hydrogen, then there will be a slight drop in pressure, if the hydrogen is consumed as a result of a current being drawn from the cell. This reduction in pressure results from the fact that there will be a flow of hydrogen down the supply ducts and tubes which will result in a change in the open circuit voltage as in Larminie and Dicks (2003)

$$
\eta_{c}=\frac{R_{u} T_{\text {cell }}}{2 F} \ln \left(1-\frac{I}{I_{l}}\right)
$$

where $R_{u}$ is the universal gas constant and $I_{l}$ is the current at which the hydrogen is used up at a rate that is equal to its supply. Another expression for the concentration loss is proposed in Larminie and Dicks (2003)

$$
\eta_{c}=-m \exp (n i)
$$

where $m$ is the electrolyte conductivity that varies with the cell temperature

$$
m=1.1 \times 10^{-4}-1.2 \times 10^{-6}\left(T_{\text {cell }}-273.15\right) \quad T_{\text {cell }} \geq 39^{\circ} \mathrm{C},
$$




$$
m=3.3 \times 10^{-3} 6-8.2 \times 10^{-5}\left(T_{\text {cell }}-273.15\right) \quad T_{\text {cell }} \leq 39^{\circ} \mathrm{C},
$$

and $n$ is the porosity of the gas diffusion layer. In this paper $n=0.3$ is used. For low current density, the concentration losses can be dispensed.

Depending on the current density and voltage output, the gross power produced by a single PEM fuel cell can be calculated as

$$
W_{F C}=V \times i \times A
$$

where $A$ is the effective geometric area of the cell $\left(\mathrm{cm}^{2}\right)$.

$$
\begin{aligned}
& \eta_{o 1}=\frac{-181.6 l_{m}\left[i+0.03 i^{2}+0.062\left(T_{\text {cell }} / 303\right)^{2} i^{3.5}\right]}{A(14-3 i) \exp \left(3.25\left(T_{\text {cell }}-303 / T_{\text {cell }}\right)\right)}, \\
& \eta_{c 2}=-m \exp (n i) \\
& V^{*}=E_{N}+\eta_{a}+\eta_{o 1}+\eta_{c 2} .
\end{aligned}
$$

The performance of the fuel cell by using Eq.(2.29) for $V^{*}$ is at a higher value which it is due to the reduction of Ohmic and concentration losses of $V^{*}$.

\section{Results and discussion}

For investigating the performance of a single cell, it is necessary to compare the results of these semi-empirical equations with an experimental result for a test setup. In this paper, the results are compared with the experimental results of Miansari et al. (2009). The PEM fuel cell used by Miansari et al. (2009) is a single cell with an active area of $25 \mathrm{~cm}^{2}$ and single-serpentine flow field geometries. The width and land width of the channel are 1 and $0.8 \mathrm{~mm}$, respectively. The channel depth is 1 and $1.5 \mathrm{~mm}$ for empirical work. For a bipolar plate, non-porous graphite is selected. The membrane electrode assembly is nafion 117 with $4 \mathrm{mg} \mathrm{Pt} \mathrm{cm-2} \mathrm{for} \mathrm{the} \mathrm{anode} \mathrm{and} \mathrm{cathode.} \mathrm{On} \mathrm{both} \mathrm{sides} \mathrm{of} \mathrm{the} \mathrm{MEA,} \mathrm{there} \mathrm{are} \mathrm{270-mm} \mathrm{thick} \mathrm{carbon} \mathrm{papers}$ that act as diffusion layers.

Table 1 presents the constants and parameters introduced in Sections 3.

Table 1. Constants and parameters used for the comparison.

\begin{tabular}{ll}
\hline$E^{\mathrm{o}}$ & $1.229 \mathrm{~V}$ at $298.15 \mathrm{~K}$ and $1 \mathrm{~atm}$ \\
$T_{\text {cell }}$ & $343,328 \mathrm{~K}$ \\
$P$ & $1 \mathrm{~atm}$ \\
$F$ & $96487 \mathrm{Cmol}^{-1}$ \\
$R$ & $8.314 \mathrm{~J}\left(\mathrm{molK}^{-1}\right.$ \\
$\lambda_{\text {air }}$ & 2 \\
\hline
\end{tabular}


Figure 2 shows the comparison of polarization curve for a single cell of experimental results of Miansari et al. (2009) and the analytical results for two different operating temperatures. It is clear that with increasing the temperature, the cell can operate at higher performance levels. This is in fact due to the decrease in activation and Ohmic losses; In other words, mass transport processes are slightly influenced by temperature changes within the typical operating temperature ranges of PEM fuel cells. Also, the results show that there is a good agreement between the predicted polarization curves and the experimental results. Of course, the theoretical results show smaller values of voltage than the experimental results and the maximum difference between the experimental and the theoretical results is about $18 \%$.

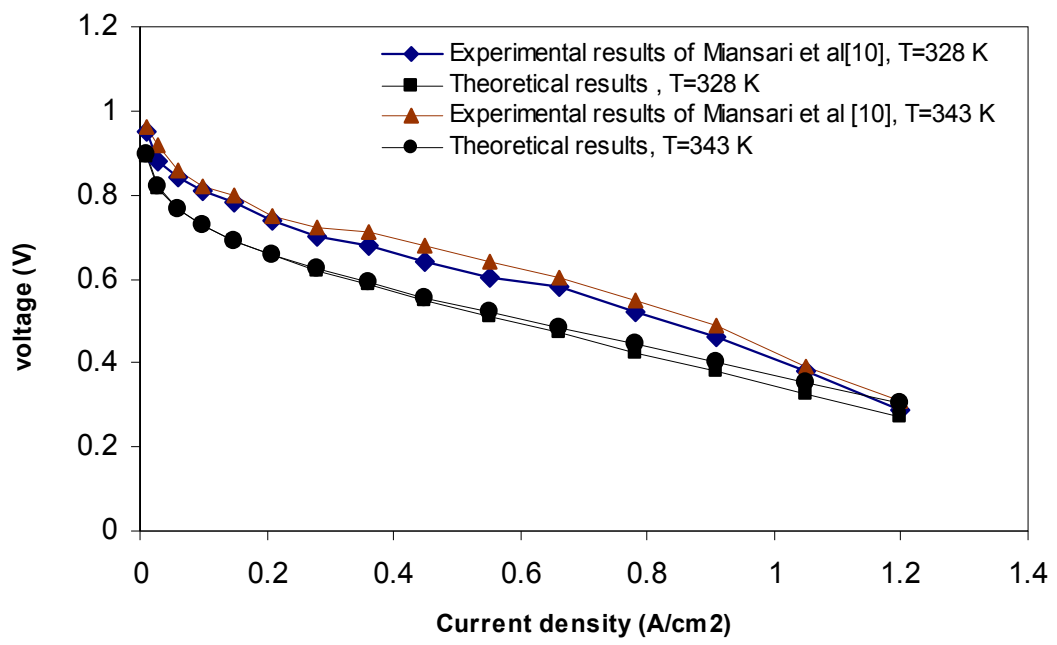

Fig.2. Validation of theoretical results of cell performance and experimental results of Miansari et al. (2009).

Figure 3 shows the effect of cell temperature on output power of a PEM fuel cell at $p=1$ bar, $\lambda_{\text {air }}=2$ and for $T_{\text {cell }}=318,328$ and $338 \mathrm{~K}$ for $V^{*}$. It is clear that increasing the cell temperature leads to the increase in the output power of the cell which is due to the decrease of voltage losses and increase in the output voltage. Also, it is clear that the maximum output power of the cell at reference conditions is obtained at current density about $0.91 \mathrm{~A} / \mathrm{cm}^{2}$. This optimum current density value, together with the other design parameters, will allow determining the number of cells of a stack of the PEM fuel cell.

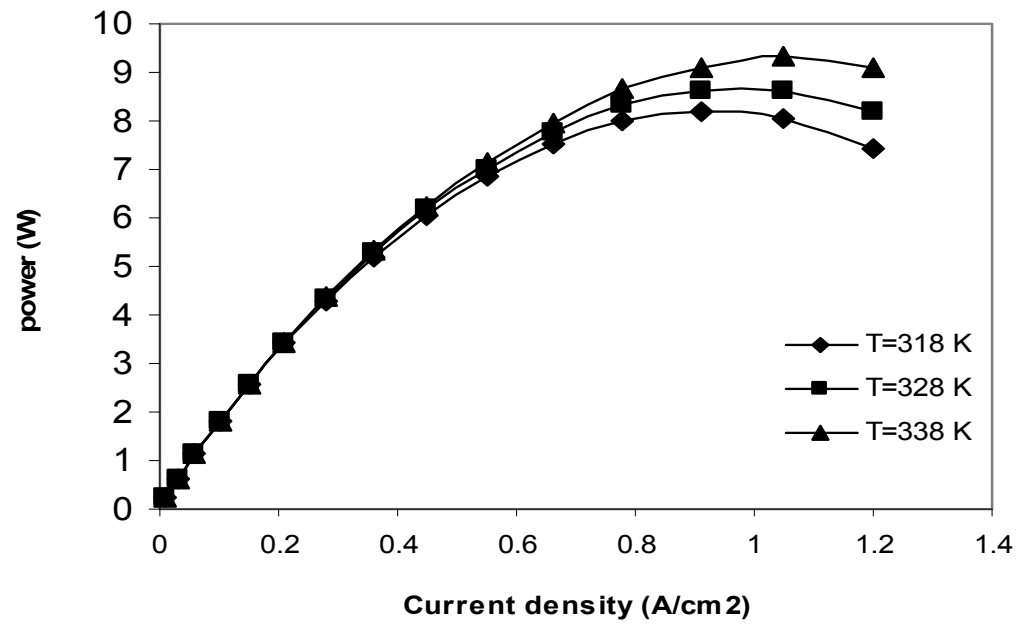

Fig.3. Variation of output power of cell at different cell temperatures. 
Figure 4 shows the effect of cell pressure on the performance and output power of a single cell at $T_{\text {cell }}=328 \mathrm{~K}$ and $\lambda_{\text {air }}=2$ for three different pressures for $V^{*}$. It is clear that an increase in pressure increases the performance and also output power of the fuel cell which is due to a decrease in Ohmic and concentration losses and increase in the open circuit voltage, reactant concentration and exchange current density. Also, it is clear that by increasing the pressure, optimum current density for maximizing the output power increases. It is necessary to identify whether these empirical correlations are affected by the fuel cell design and material of membrane and electrodes.
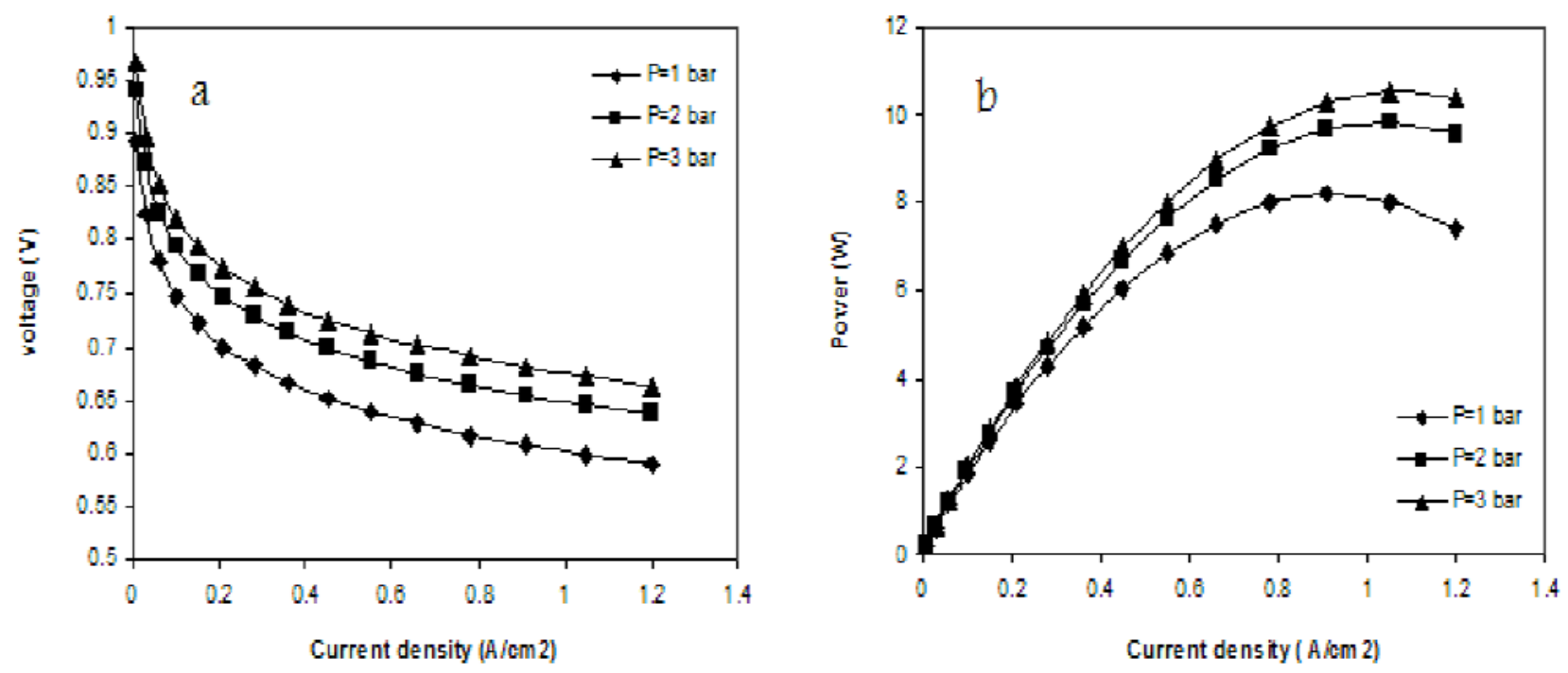

Fig.4. Variation of a) cell performance and b) output power of a fuel cell at different cell pressures.

In Fig. 5 the effect of air stoichiometry on the cell performance and output power is shown for $p=1$ bar and $T_{\text {cell }}=328 \mathrm{~K}$ for three different values of stoichiometry of air and for $V^{*}$. It can be observed that increasing the air stoichiometry increases the output power of the cell but there is no appreciable increase in the cell performance. Also, it is clear that the maximum output power of the cell at reference conditions is obtained at current density about $0.91 \mathrm{~A} / \mathrm{cm}^{2}$.
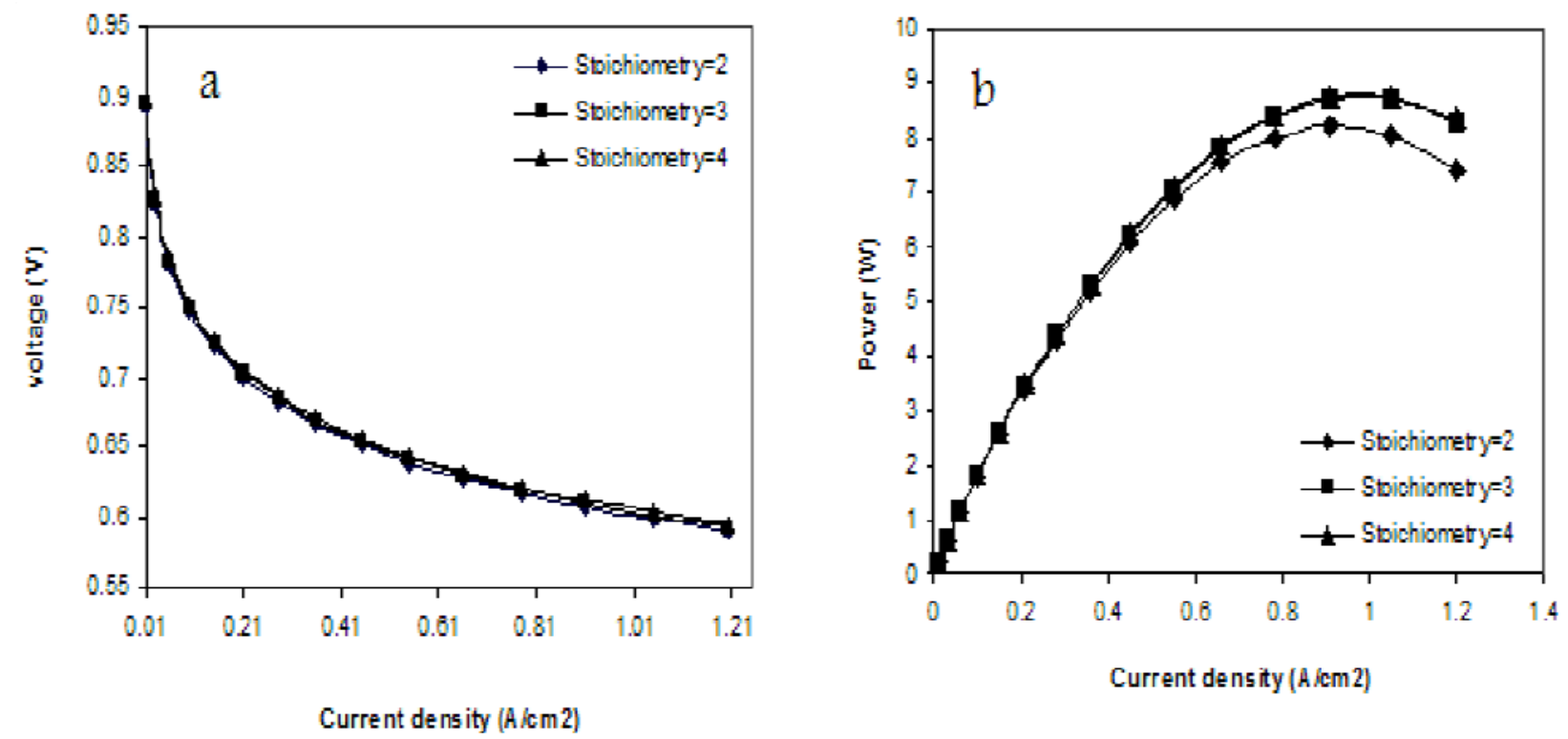

Fig.5. Variation of a) cell performance and b) output power of a fuel cell at different air stoichiometry. 


\section{Conclusion}

In this study, the effects of cell temperature $\left(T_{\text {cell }}\right)$, cell pressure $(p)$ and air stoichiometry $\left(\lambda_{\text {air }}\right)$ on the performance and voltage losses in a PEM fuel cell were investigated and a comparison of the theoretical and empirical equations was presented. It is found that:

- Increasing the cell temperature and pressure and also increasing the air stoichiometry can enhance the cell performance.

- There is a good agreement between the experimental results of Miansari et al. (2009) and the theoretical results of this study.

- By combining the theoretical and empirical equations of losses, the performance of a PEM fuel cell can be improved and it was found that Eq.(2.29) is the best choice for predicting the polarization curve of a PEM fuel cell at different operating conditions.

- The performance of a fuel cell for empirical correlations at current density of about $i=0.2 \mathrm{~A} / \mathrm{cm}^{2}$ may be changed by varing the cell temperature.

\section{Nomenclature}

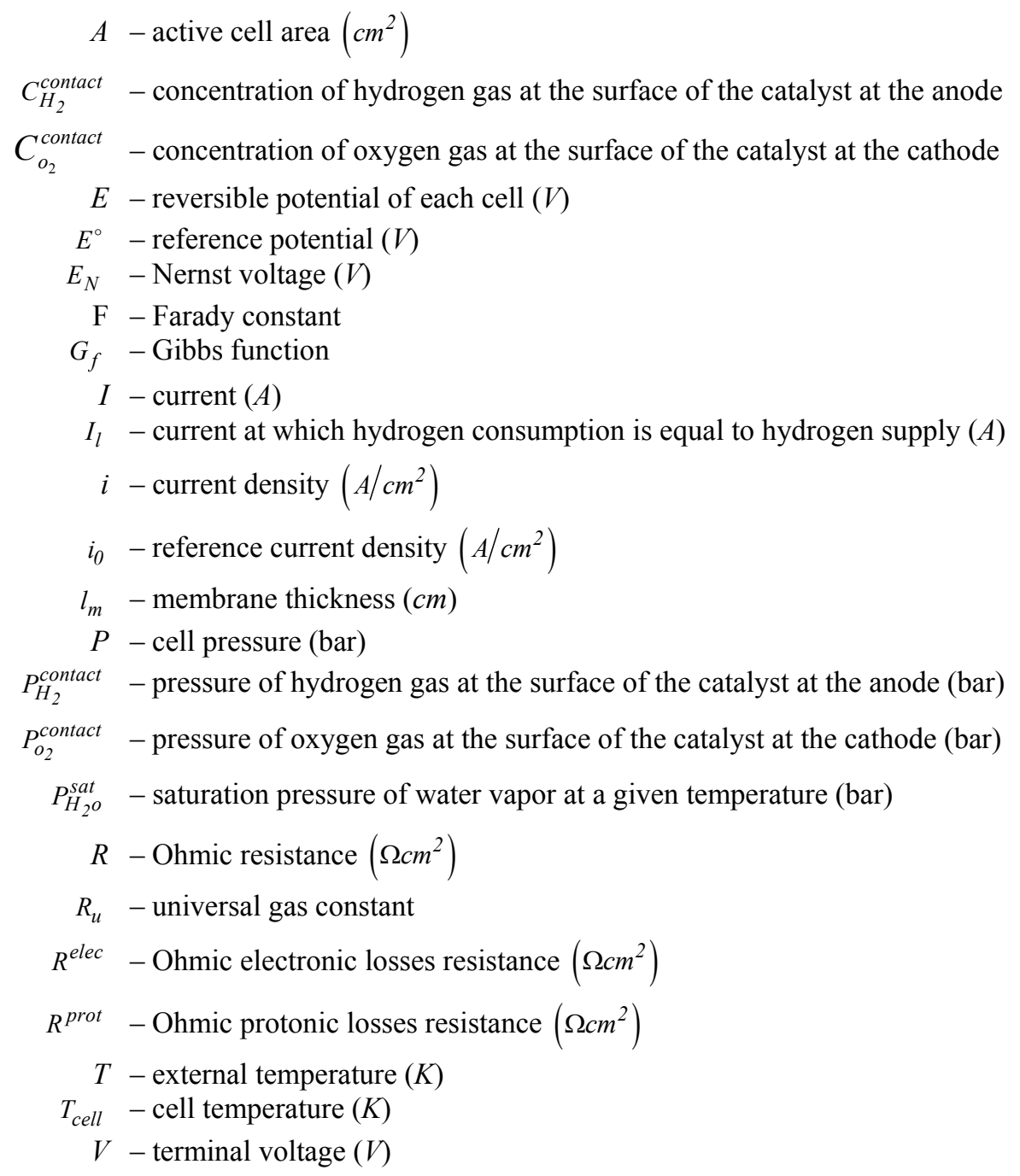




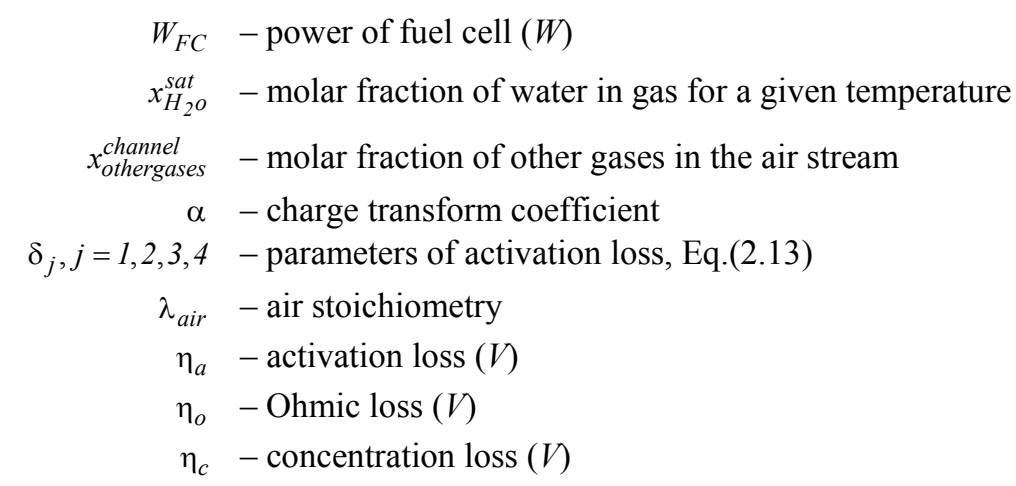

\section{References}

Amphlett J.C., Baumert R.M., Mann R.F., Peppley B.A. and Roberge P.R. (1995a): Performance modeling of the Ballard Mark IV solid polymer electrolyte fuel cell. I- mechanistic model development. - Electrochemical Science and Technology, vol.142, pp.1-8.

Amphlett J.C., Baumert R.M., Mann R.F., Peppley B.A. and Roberge P.R. (1995b). Performance modeling of the Ballard Mark IV solid polymer electrolyte fuel cell. II - empirical model development. - Electrochemical Science and Technology, vol.142, pp.9-15.

Crockett G.M., Newborough M., Highgate D.J. and Probert S.D. (1995a): Electrolyser-based electricity management. Applied Energy, vol.51, No.3, pp.249-263.

Frangopoulos C.A. and Nakos L.C. (2006): Development of a model for thermoeconomic design and operation optimization of a PEM fuel cell system. - Energy, vol.31, pp.1501-1519.

Larminie J. and Dicks A. (2003): Fuel cell system explained. $2^{\text {nd }}$ ed. - Wiley.

Lazarou S., Pyrgioti E. and Alexandridis A.T. (2009): A simple electric circuit model for proton exchange membrane fuel cells. - Journal of Power Sources, vol.190, pp.380-386.

Mann R.F., Amphlett J.C., Hooper M.A.I., Jensen H.M., Peppley B.A. and Roberge P.R. (2000): Development and application of a generalised steady-state electrochemical model for a PEM fuel cell. - Journal of Power Sources, vol.86, (1/2), pp.173-180.

Miansari Me., Sedighi K., Amidpour M., Alizadeh E. and Miansari Mo. (2009): Experimental and thermodynamic approach on proton exchange membrane fuel cell performance. - Journal of Power Source, vol.190, pp.356-361.

Scrivano G., Piacentino A. and Cardona F. (2009): Experimental characterization of PEM fuel cells by micro-models for the prediction of on-site performance. - Renewable Energy, vol.34, pp.634-639.

Xue D. and Dong Z. (1998): Optimal fuel cell system design considering functional performance and production costs. - Journal of Power Sources, vol.76, No.1, pp.69-80.

Received: December 2, 2013

Revised: March 7, 2015 